\title{
The Existence of Transmigration Settlement In The Village (a Case in Transmigration Settlement in Mulawarman Village, Kutai Kartanegara Regency)
}

\author{
Jumansyah \\ Department of Government Science Padjadjaran University, \\ Bandung Indonesia \\ Utang Suwaryo \\ Department of Government Science Padjadjaran University, \\ Bandung Indonesia \\ Neneng Yani Yuningsih \\ Department of Government Science Padjadjaran University, \\ Bandung Indonesia
}

\begin{abstract}
Transmigration settlement is an integral part in the implementation of transmigration programme. The existence of transmigration settlement in a village, including at Mulawarman Village, is the responsibility of the local government as the implementer of transmigration program in regency/city scale in supporting and preserving the settlement to become a settlement that is feasible for a place to live, for work, and for development. The existence of transmigration settlement, in reality, still becomes the main problem for transmigration community to obtain better life since the role of local government as a regulator has not maximal in making policy related to transmigration settlement as well as their role as a facilitator in creating physical development to support all activities conducted by the transmigration community and their role as a dynamic driving forces to drive the aspiration of the transmigration community. Therefore, the existence of transmigration settlement in the village is endangered.
\end{abstract}

Keywords: The role of local government, regulator, dynamic driving forces/driver, transmigration settlement

\section{INTRODUCTION}

The existence of transmigration settlement is an important indicator in the implementation of transmigration program in Indonesia. The existence of decent transmigration settlement in Indonesia is the manifestation of local government responsibility as the implementer of transmigration program in regency/city scale ${ }^{1}$. In the context of transmigration implementation in regional autonomy era, it is a part of authority of local government. In this case, the task of transmigration program implementation is in the hand of local government. Local government is demanded to be able to response to challenge, utilize the potential and opportunities to view transmigration as a way to prospering the society in its area and Indonesian society as a whole (Suparno, 2008).

${ }^{1}$ PP RI No 3/2014 on the Implementation of Transmigration:: article 4 paragraph (2), provincial government is responsible on the implementation of transmigration in provincial scale. Paragraph (3), the government of regency/city is responsible on the implementation of transmigration in their own scale. 
From the centralistic era to decentralization era, the government continues to improve the management of transmigration program. It is indicated by the issuance of Law No. 29, 2009 on the change of Law No. 15, 1997 on Transmigration. In addition, due to the implementation of the law, the government issues the Regulation of the Government of the Republic of Indonesia No. 3, 2014 on the Implementation of Law No. 29, 2009 on Transmigration. Transmigration settlement, based on Law No. 29, 2009 on Transmigration, is understood as a unit of settlement reserved for a residential area and a business location for the transmigrants. In addition, the settlement is a potential location determined as transmigration settlement to support the center of growth of new areas in a region².

In the context of transmigration, it can be said that transmigration program is a real form of government action to reduce population density and to improve the life quality of the society since through the program the society is expected to be able to improve their own standard of living compare to their original place; therefore, it can be understood that transmigration program is a long term program thus the regency/municipal government as the implementer of the program is demanded to be the leading organization in achieving the goals of the program. According to Muttalib and Khan (2013), conceptually, local government is multidimensional thus they play important role in supporting all aspects of life of the society in the region, including giving special attention on the development of transmigration settlement in their areas.

However, as time goes by, the implementation of transmigration program still faces various problems. Those problems, according to Sardjadidjaja (2004), among others, are: first, the occurrence of social jealously from local resident on the success of or facilities given to the transmigrants; second, the existence of impression of the exploitation of natural resources by certain group, tribe, and investor with no consideration on the interest of local societies and the transmigrants; third, the existence of locations or transmigration settlements that relatively isolated where the road facilities and infrastructures are damaged causing the price of transmigration products is low, whereas the price of daily necessity is high; four, the ineffective of understanding from the implementer of transmigration on the concept of steering rather than rowing thus the service given is not entirely perceived by the transmigrants and local resident; and five, environmental degradation indicating by land degradation and inefficient utilization of productive land thus many lands are abandoned in several locations of the existing transmigration settlement.

Therefore, in the implementation of transmigration program, local government takes control of their area and it is hoped that the government is able to improve their roles to maintain the existence of transmigration settlement in the village. In this case, the role as a regulator is the role that demanded the local government to formulate regulations that could accommodate all interests of the society especially in maintaining the existence of transmigration settlement, whereas, the role of local government as a dynamic driving forces/driver is aimed at driving the aspiration of the society especially the transmigration community in regional development. Further, the role of the local government as a facilitator is aimed at facilitating the transmigration community in fulfilling their needs in all life aspects. Therefore, all issues or

\footnotetext{
${ }^{2}$ Law No. 29, 2009 on Transmigration, article 1 paragraph (8) stated that transmigration settlement is a unit of settlement or part of a unit of settlement aimed for residential area and business location of the transmigrant. Further, article pasal 1 paragraph (6) stated that settlement location of transmigration is a potential location determined as transmigration settlement to support the center of growth of the existing or developing areas as new rural areas based on the spatial plan.
} 
obstacles faced by the transmigrant will be solved and it could create a sustainable transmigration settlement.

The paper was not intended to examine the implementation of transmigration program in the level of local government as a whole, instead it tried to explore the role of local government of Kutai Kertanegara as a regulator, facilitator, and dynamic driving forces/driver in maintaining the existence of transmigration settlement in Mulawarman Village since the settlement is a crucial part that influence all forms of life activities of the transmigration community; therefore, the support and responsibility of local government is required to create a decent transmigration settlement and sustainable for the life of the transmigration community.

\section{THE ROLES OF LOCAL GOVERNMENT AND THE EXISTENCE OF TRANSMIGRATION SETTLEMENT}

Transmigration settlement becomes the main factor in determining the success of transmigration program conducted by the government, local as well as central governments. Transmigration settlement is the center of transmigration development area planned by central as well as local governments based on the condition of each area. Transmigration settlement is a place where all activities of the transmigrants take place in order to improve their life quality as well as a place to live or settle for transmigrant from various areas who are participating in the transmigration program (Heeren, 1979). Therefore, the role of local government as the government administrator in regional level cannot be separated from the context of the implementation of transmigration program in the region, especially in maintaining and preserving the existence of transmigration settlement as a place that is feasible for a place to live, for work and for development.

Government can be defined as a government (body) and activities called government (Ndraha, 2003). Therefore, government has role or function of regulation, service, empowerment, and development. The function of regulation means that government is required to issue policies that can be used as a base and limit for society's actions. Service function means that government should be able to serve in order to fulfill the needs of the society. Empowerment function is aimed to create an independent society as a whole. Development function will achieve distribution of welfare for all societies (Rasyid in Labolo, 2007). Among those roles, Soewargono and Djohan (in Labola 2007) emphasized that the main role of government is to make a policy that concern about the common interest. In order to do their jobs or roles, government should be able to put themselves before the society so that they could play their role as a driver of society participation (Labolo et al., 2015). The main objective of government is human; therefore, government should direct their action towards a good goal to avoid loss to the human (society) life in the future (Poelje, 1953).

The existence of inseparable relationship between society and central as well as local government in government (Syafiie, 1994) required the government to give solution for different common interests (Anthony Giddens and Ndraha, 2005); therefore, government should be able to translate all aspects related to the life condition of the society so that their action could support and encourage the improvement in physical and non-physical development (Ndraha, 2005). The role of government can be improved in the following ways: first, reduction of obstacles and constraints for society creativity and participation and second, expansion of service access to support various socio-economic activities of the society (Sedarmayanti, 2012).

On the other side, local government should be the generator or driver of participation of all society layers, including transmigration community and should be able to look and anticipate 
circumstances. In other word it is better to prevent the occurrence of various possible obstacles than overcome them in the future (Syafiie, 2011). Local government plays a very important role in realizing all society expectations in living their lives; in other words, society life will not run normally without intervention of local government in their life including in transmigration community. Therefore, local government should be able to implement their role maximally to avoid negative stigma among the society. The role of government, in this case the role as regulator, is intended for making policies, public control and supervision, public and private sector protector, facilitating state and public interests, and public service (Rasyid in Rosidi and Fajriani, 2013).

From various roles of government, especially local government, there are three roles that become the main role of local government in government administration to support the development that could prosper the society, including the transmigration community in the area. Those roles are regulator, facilitator and dynamic driving forces/driver. Government as a regulator is expected to issue or make policies based on common interests and create justice for all societies since after all, the societies will be affected by those policies; therefore, government policies are expected not to benefited one party and harm others. Government as a facilitator required them to be able to provide services to fulfill the needs of society, such as physical and non-physical development, in order to create society life quality and give easiness for all societies to live their life aspects. Government as a dynamic driving forces/driver meant that they should become a driver or generator of society aspiration and response all obstacles faced in the society life as well as encourage the creation of societies that are independent in all life aspects and it can be done by launching programs that influence all society layers and give assistance to the society in form of special trainings and other trainings.

Local government should be able to implement their roles in synergy with the expectation of local society (Suharto, 2016). Regarding the role of local government in the implementation of transmigration program ${ }^{3}$ it is particularly related to maintaining the transmigration settlement in the village which is an interrelated and inseparable system. Transmigration settlement becomes the main factor in determining the success of transmigration program conducted by the government, central and local. It is the center of transmigration development area planned by the government according to the condition of their own areas. Heeren (1979) stated that transmigration settlement is a place where all activities of the transmigrant take place in order to improve their life quality as well as a place to live or settle for transmigrants from certain areas participating in transmigration program.

Transmigration settlement should be built as a place that able to support all aspects of life of the transmigrant. Therefore, the selection of areas for transmigration settlement should be well planned in order to support the sustainability of transmigrant existence. The preparation of transmigration settlement is aimed at the achievement of a settlement that is feasible for a place to live, for business, and for development and environmentally feasible (Sardjadidjaja, 2004) thus the local government should be a facilitator for the supply, regulation and direction of productive labors (Sardjadidaja, 2014).

Coaching and development of the existing transmigration settlements and the surrounding communities lead to economic improvement and political and socio-cultural consolidation through an integrated implementation (PPSM, 1980). Therefore, transmigration settlement is

\footnotetext{
${ }^{3}$ Regulation of the Government of the Republic of Indonesia No. 3, 2014 on the Implementation of Transmigration, article 4 paragraph (3) stated that: the implementation of transmigration in the regency and city level is the responsibility of the government of regency/city
} 
part of plan that involves local government in order to achieve the implementation of transmigration program as a sustainable regional development. Transmigration settlement is an arena where transmigrant community is doing their activities to fulfill their needs and to achieve better life compare to their previous life (in their origin place). In other words, transmigration settlement is the main factor influencing the life of the transmigrant (Heeren, 1979). The settlement is directed toward a settlement where the main work is in food crops, plantation crops, livestock, fishing farmers and pond farmers (Fitriyah, 2016).

However, it will not be achieved without the support of a sustainable transmigration settlement planning from the government, especially local government that in charge in the implementation in their areas; therefore, up to now, settlement issue for the transmigrants is still the causing factor of the likely stagnant transmigration program. It is particularly when looking at the condition of the settlement in certain rural areas. Local government as the closest government level and directly in charge on the societies in their areas should response to all obstacles faced by the societies, especially transmigration community who live in the rural areas. In addition, with the development of transmigration areas in rural areas, local government is demanded to have doable plan based on the priority needs of local society, especially transmigration community.

In the context of the existence of transmigration settlement in the implementation of transmigration program in a region, the role of local government is directed towards the following: First, the role of government as a regulator requires local government to be able to make policy that could overcome problems faced by transmigration community. It is intended to sustainably support the existence of transmigration in the area since transmigration program is viewed not only as a migration but also as a program that has socio-economic impacts and improve the regional development; Second, the role of government as a facilitator requires local government to be able to provide basic needs related to the existence of transmigration program by, among others, providing a decent settlement as a place to live and to work for the transmigrant; and Third, the role of government as a dynamic driving forces/driver requires the government to be a driver for society participants in developing an independent society including transmigration community to response to all obstacles faced by the society especially transmigration community in their area.

Based on the above description, framework built as the basic of the research is:

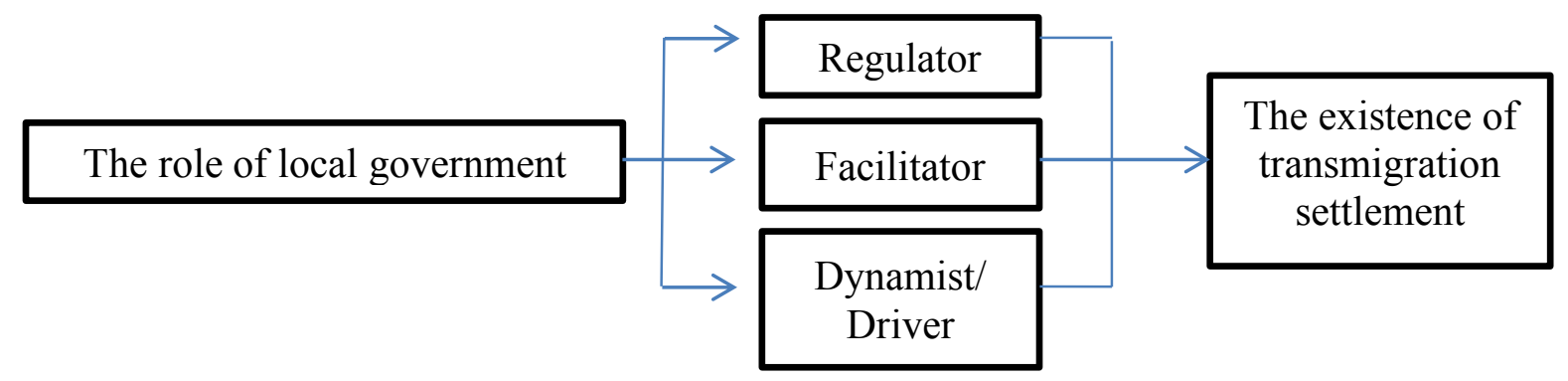

Figure Framework Model

RESEARCH METHOD

Method used in the research was qualitative method with explorative analysis approach. The method was considered as relevant to the research to be conducted to obtain real understanding regarding the roles of local government in maintaining the existence of transmigration settlement. In addition, qualitative method was expected to be able to explore and understand the meaning of a problem to be examined. The research process involved 
important efforts, for example, asking questions and procedures, collecting data inductively from specific themes to general themes and interpreting the data (Creswell, 2016). Moreover, a research with qualitative method involves author as the key instrument in a research. Therefore, information and data related to the research context of the role of local government in maintaining the existence of transmigration settlement was obtained from direct interaction between the author and the research participants thus information and data obtained was real and without manipulation.

Creswell (2016) stated that qualitative research is not only based on one data source. The main data source in qualitative research is words and actions and the rest of the data is additional data, such as documents and so on. Thus, type of data is divided into words and action, written data sources, pictures and statistics (Lofland and Lofland in Moleong, 2005). Some data sources are obtained through the following techniques: observation, interview, and documentation. Observation is an effort conducted by the author by conducting direct observation to object being researched to gain information and data corresponding to the phenomenon or symptoms related to the context of the role of government as regulator, facilitator, and dynamic driving forces/driver in maintaining the existence of transmigration settlement. Interview was conducted to gain clear and deep information from the informants who understand the research context. Therefore, authors obtained response and opinion from the informants on data or information needed in the research. Further, documents in the research were those documents in form of: laws, government regulations, regional regulations, pictures and other documents considered related to the research and supported the related research context.

This paper used interactive qualitative data analysis. As explained by Miles and Huberman (in Sugiyono, 2009) "activity in qualitative data analysis is conducted interactively and continuously until it completes and data has saturated". Activities in data analysis are: data reduction, which is summarizing and selecting the key points and focusing to important things, looking for the theme and patterns thus data that has been reduced will give clearer picture and facilitate the author to collect and look for further data if needed; data display is the next step after data reduction, which is presenting data in form of short description, charts, relations between categories, flowchart and else; thus it facilitates the author to understand what is happening and to plan for next work based on the understanding; and conclusion drawing or verification where authors draw conclusion after systematically or regularly going through the previous stages. The initial conclusion stated by the author is a tentative conclusion since it should be verified first to find valid evidences related to the initial conclusion and if it is supported by valid evidences then the conclusion is a credible conclusion.

\section{THE ROLES OF LOCAL GOVERNMENT AS REGULATOR, FACILITATOR AND DYNAMIC DRIVING FORCES/DRIVER IN MAINTAINING THE EXISTENCE OF TRANSMIGRATION SETTLEMENT IN THE VILLAGE}

The development of transmigration settlement is a part inseparable from the local government step to make policies and programs that could bring impact to the life of transmigration community. Local government policies in the development of transmigration settlement are expected to become a guidance or foundation in creating order and developing transmigration settlement areas. The condition of transmigration settlement can be seen from various feasibility standards and the standard is a mandatory requirement in a transmigration settlement area. The feasibility standard is related to the feasibility for a place to live, to work and to be developed; therefore, the existence of transmigration settlement should be in accordance with the determined standards. 
However, based on the standards, the local government, especially the government of Kutai Kertanegara Regency, as the implementer, had not been able to implement the standard. The implementation of transmigration program in Kutai Kertanegara Regency had not have consistency to achieve the expectation of transmigrant community, especially those who lived in Mulawarman Village. Transmigration settlement in the village was far from the standard. It did not meet the standard of feasible to be occupied, to be a place to work, and to be developed. The condition occurred in the transmigration settlement in the village was an important lesson to re-evaluate the pattern of the development of transmigration settlement in the village.

The role of local government in the context of maintaining the existence of the endangered transmigration settlement was not an impossible role since the government has the responsibility for the implementation of transmigration program in the regency scale. One of local government actions that should be worked was the ability of the government to create regulation or policy that could protect the transmigration settlement areas and create order as well as give security to the transmigration community. In addition, local government should create programs that bring direct impact on the life of transmigration community; therefore, the existence of transmigration settlement development program by local government was one of the main factors in realizing an independent transmigration community and encouraging a new economy in the settlement.

Without those programs and policies to overcome the existing problems in transmigration settlement, it would create anxiety among the transmigrants especially related to the improvement of their livelihood in agricultural field. Meanwhile, despite the existence of proposed regional regulation on transmigration initiated by DPRD (regional representative council), no agreement obtained up until now regarding the regulation from the local government of the regent of Kutai Kertanegara. All the expectations were resided in the hand of local government as the decision maker. Therefore, what happened in Mulawarman Village was the negligence of the local government in implementing, protecting and maintaining transmigration settlement area. In addition, although government had provided a program, which was livestock program, it was not enough to influence the improvement of economy among the community, since they found difficulty in running the program due to the lack of green lands as a place to manage the livestock program. 


\section{Figure: the role of local government as a regulator that was not maximally worked in} maintaining the existence of transmigration settlement

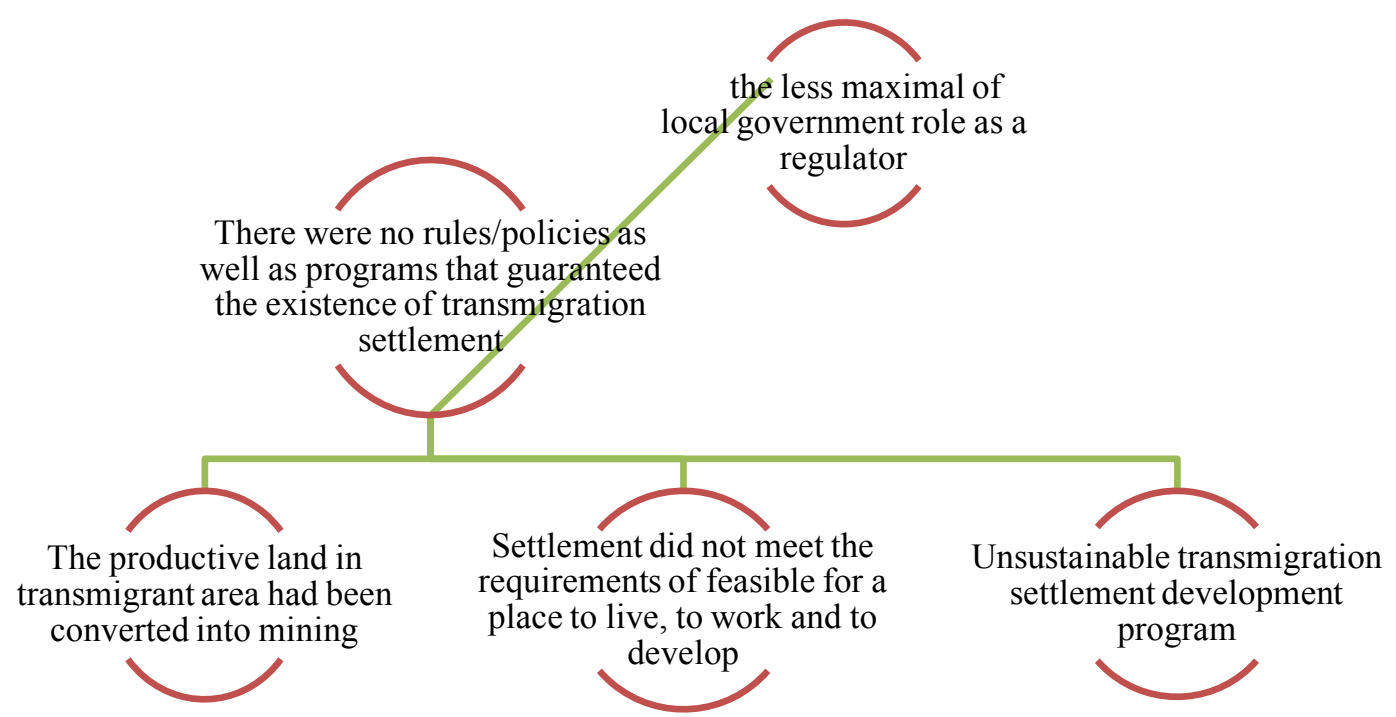

Regarding the role of government as a regulator, it can be concluded that the government had not played their role maximally in maintaining the transmigration settlement. It can be proven from the less supervision conducted by local government on the continuity of transmigrations settlement. In addition, currently there was no regulation or policy that can be used as a base for the community to maintain their settlement that increasingly eroded by the existence of mining in the area causing the productive lands shifted into coal mining land. It indicates the helplessness of the transmigration community due to the less optimum of local government role as a regulator in preserving and maintaining the existence of transmigration settlement. If the optimization did not conducted it was likely that in the future, the condition occurred in the transmigration settlement area in Mulawarman Village could occur in other settlement areas in Kutai Kertanegara Regency.

Moreover, in the context of local government as a facilitator to support the need of transmigration community, physical development, such as road availability as a support for community activities, was the priority for transmigration settlement. In the effort of the development of transmigration settlement area in Mulawarman Village, local government of Kutai Kertanegara Regency, as a facilitator, was intended to be present as a provider of facilities to support the transmigration program in their area. Development transformation up to the ultimate stage should be placed as the forefront in planning strategic areas in order to improve the prosperity of transmigration community. The development of transmigration settlement was not only considered as the need of transmigrants but it was also acted as an effort to support new economic centers in the areas with potential to be developed.

Transmigration settlement area in Mulawarman Village was initially a new reliable economic center in agricultural sector since the village is the granary of Kutai Kertanegara Regency. However, eventually, the village became a threat for the community who lived in the village. Agricultural sector that previously became the mainstay of the transmigration community had been replaced by coal mining fields that suppressed the life sustainability of the community.

The role of government as a facilitator seemed to have no impact on the development of transmigration settlement and it eventually threatened the existence of the settlement in Mulawarman Village. In addition to the decreasing of land that turned into mining land, the 
condition of physical development, especially village and economic roads, was another problem for the transmigration community in the village. The difficulties in transportation facilities had worsen the condition of the transmigration community. It was related to how the involvement of the local government in responding obstacles faced by the community and translated them into development program in the settlement area.

On the other side, the government of Kutai Kertanegara Regency had made an agreement with companies, village government and local society to overcome problems occurred in Mulawarman Village. The agreement was related to clean water, the creation of new rice fields, road repair, and health improvement. However, there was no real action yet from the local government regarding the agreements. Returning the rights of transmigration community was a crucial process to be conducted in order to restore the economic development of the community.

Regardless of that, all problems in the transmigration settlement in Mulawarman Village were a great concerned especially the realities behind the problems. Transmigration community was worried about everything that occurred in their community since the impacts were increasingly indicated their helplessness thus it threatened their residential place in addition to their long gone agricultural land. Waste pollution and cracked building caused by mining activities were among the impact perceived by the society and there were the indication that the transmigration settlement in Mulawarman Village was no longer met the standard of feasible as a place to live, to work, and to develop. Therefore, it was reasonable that the community expected assistance from the local government to solve the problems since it was the local government that held the responsibility on the implementation of transmigration program in the area.

The problems were not only limited to those problems related to facilities available in the village, the transmigration community was not only the victim of the weak support of the local government but they were seemed to had been forced to stay without any certainty to hold on to in facing the challenge of unsuitable settlement. The condition of road infrastructures, land, and clean water needs were the main challenges for the community. In one occasion, they were hoping that lands owned by the company could be lent to them for farming. However, the solution was never came to realization among the transmigration community in Mulawarman Village since the final decision would be in the hand of local government of Kutai Kartanegara Regency as the authorized party.

Back to the main problems in the transmigration settlement area in Mulawarman Village, all efforts expected from the local government of Kutai Kartanegara Regency was far from the expectation of the community. Every necessity required to support their activities, such as road infrastructure, clean water, and health service, had not been realized by the local government. 


\section{Figure: The Reality of the Implementation of the Role of Government as a Facilitator in} Maintaining the Existence of Transmigration Settlement

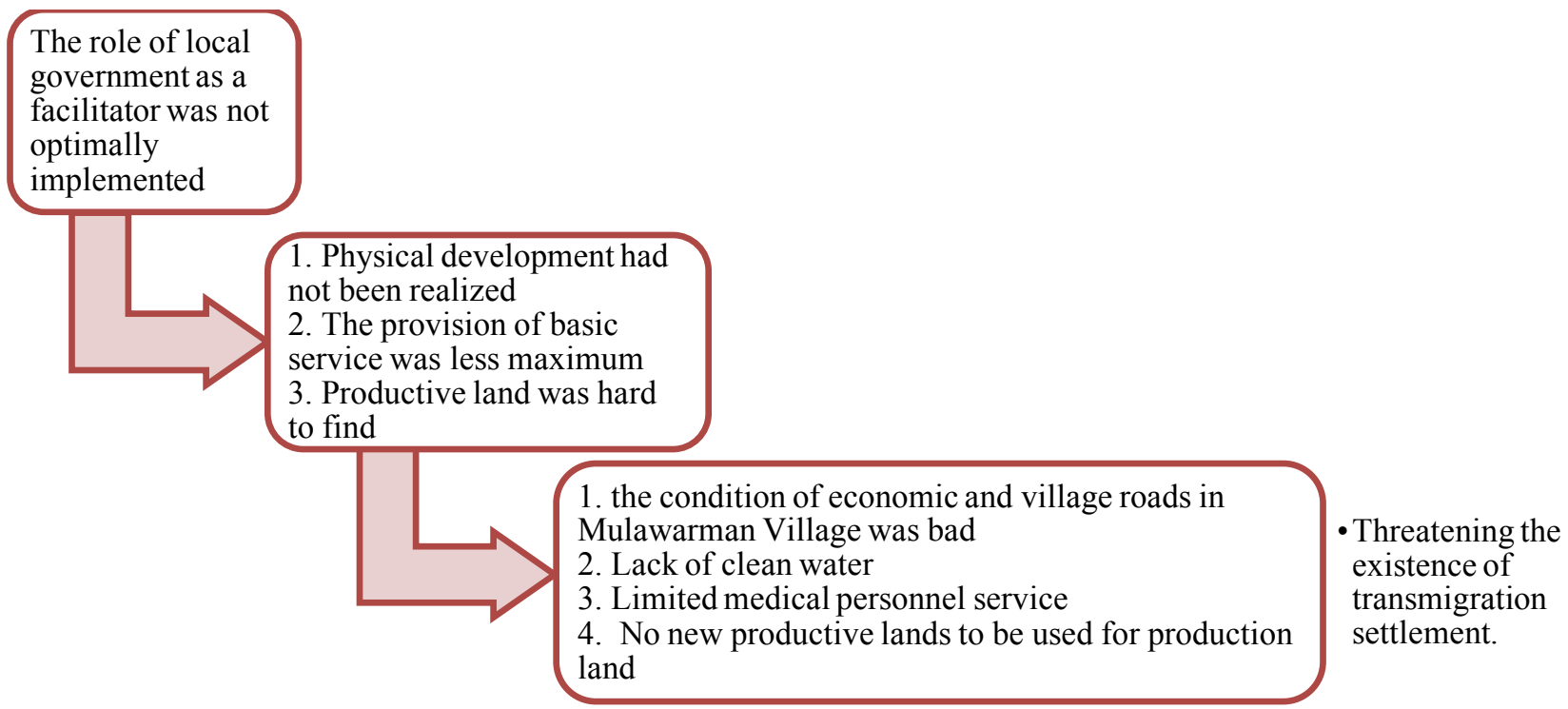

Local government as a facilitator in maintaining the existence of transmigration settlement seemed to be far from the expectation of the community based on what had occurred in the community. Transmigration program in Kutai Kertanegara Regency that basically acted as a way to give multidimensional impact, in reality, it brought complicated problems for the community that already put so much expectation into the program. Therefore, new transformation was needed related to the effectiveness of the government role as a facilitator in the implementation of transmigration program so that all limitation conditions occurred in transmigration settlement area could be managed to create a sustainable settlement to maintain the existence of transmigration settlement in the region.

The involvement of society in the development is a requirement in creating a fair development and a development that is in accordance with the priority scale of local society needs, especially for those who live in transmigration settlement areas. The development of transmigration settlement in order to maintain the existence of the settlement can be conducted by involving local government as a dynamic driving forces or driver for the aspiration of transmigration community. In this way, the government of Kutai Kertanegara Regency could manifest it in form of planning that oriented to the priority scales of society needs. It was in accordance with a regulation stating that the development of transmigration settlement area should be conducted through an approach to society needs. Therefore, the role of local government as a dynamic driving forces/driver is an inseparable part of all local government roles in maintaining the existence of transmigration settlement in Mulawarman Village. Referring to the understanding and based on the phenomenon occurred in the transmigration settlement in Mulawarman Village and related to the efforts to encourage society development and independence in transmigration settlement areas, then the transmigration community should have what they had expected to overcome the gap. However, the problem was that their demand and aspiration would never found their way since there was no realization from the local government. Thus, it was reasonable that the trust of the community to the local government of Kutai Kertanegara was eroded, especially due to the fact that the government of Mulawarman village had previously asked for assistance to the central government regarding problems in the transmigration settlement in their areas. 
The important point from the above explanation is that it could be understood that the weak attention of local government to the completion of transmigration settlement problems had forced the community to ask for assistance to the central government although it was unreasonable action to be done by community transmigration in the village since there was local government that is considered as having the responsibility for the implementation of transmigration program in their area.

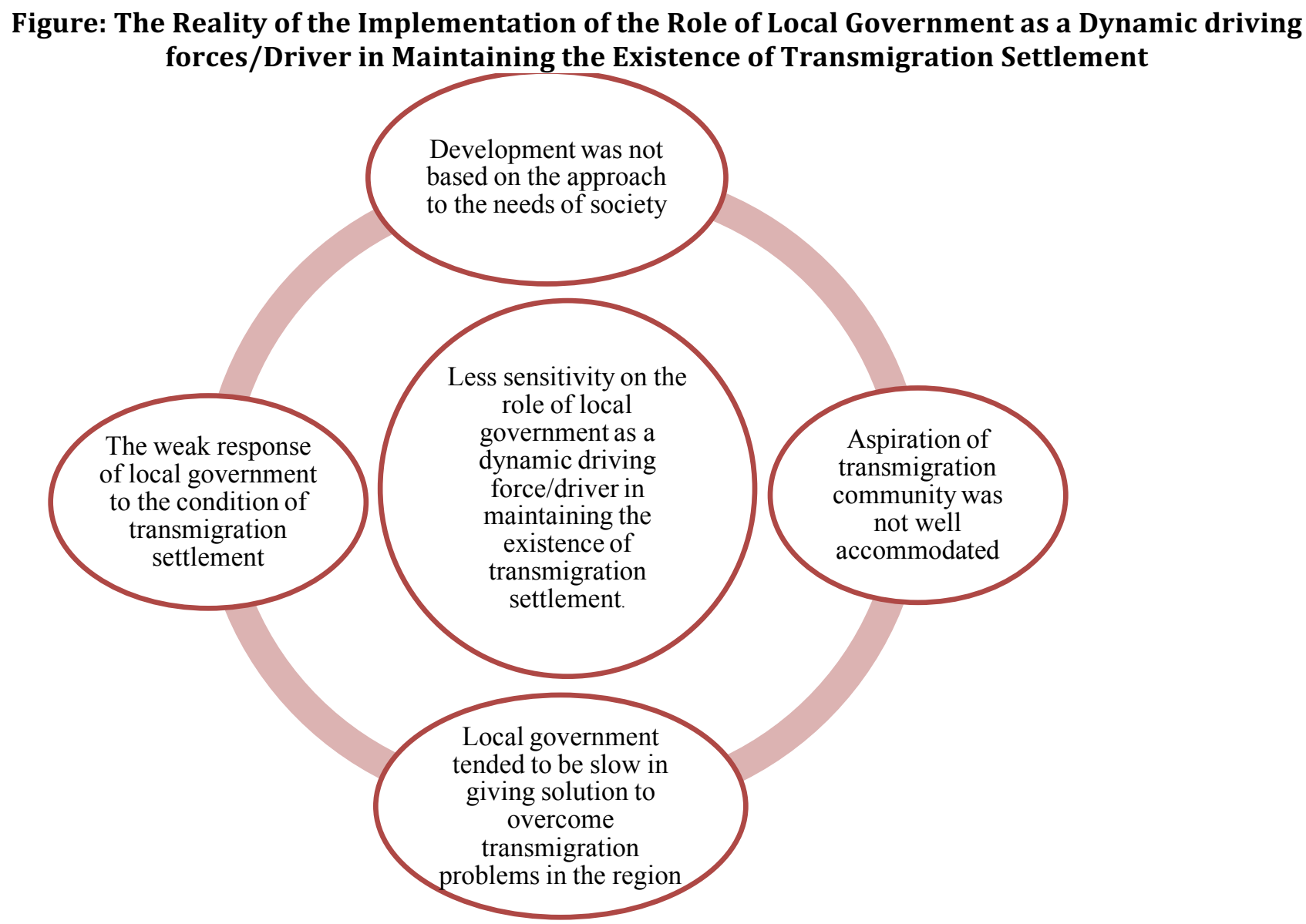

Problems regarding the condition of transmigration settlement in Mulawarman Village had impact on the weak of economic sector due to the limited availability of productive lands that support agricultural business of the transmigration community. Land, as an agricultural tool in Mulawarman Village with rice field of around $450 \mathrm{Ha}$, was very adequate to improve the prosperity of the community; however, currently the remaining land was only $20 \mathrm{Ha}$. In addition, problem in infrastructure development was one of the causes in the development of transmigration settlement in the village. No immediate response from the local government regarding the aspiration and needs of the community, such as the creation of new rice field and road repair, could give prolonged negative impacts for transmigration community.

Therefore, in the context of the role of local government as a dynamic driving forces/driver in protecting and maintaining transmigration settlement, it can be concluded that the role were still unable to be optimized by the local government in the implementation of transmigration program that in turn brought impact that threatened the existence of the settlement in Mulawarman Village. This was the real correction that needed to be noticed to develop a transmigration settlement that could support the life of the transmigrant. If the role of local government as a dynamic driving forces/driver did not worked well in the implementation of transmigration program in the region, the program would be disoriented from its initial 
multidimensional goals, which was to equitable development in economy, politics and sociocultural for regions outside Java Island.

The existence of transmigration settlement that is feasible for work, for a place to live and for development is a mandatory as a benchmark in the implementation of transmigration program. Local government as the receiver of transmigration community required to make sure the fulfillment of the standards so that the implementation of transmigration program could improve the life of the transmigration community compare to the life in their origin place. Transmigration area should be viewed as lively areas instead of dead areas. It means that the area, as optimal as possible, can become a prospective area for investment. Therefore, transmigration area is not only a place to accommodate people who migrate from one island to another island (Suparno, 2008). By putting forward the concept of transmigration settlement area development that is suitable and avoiding all the possibilities that could threaten its existence, the local government will succeed as an institution that in charge in the implementation of transmigration program in their area. However, if the local government is unable to minimize the threats that could damage the transmigration settlement, then the settlement would gradually disappear. Based on the discussion, the existence of local government that plays active role in the implementation of transmigration program in the region was needed for the continuity of everything that support the program so that the program could run as pre-determined rules.

Problems related to the existence of transmigration settlement in rural areas became important in this discussion since the settlement was a crucial part in the discussion of transmigration. Transmigration settlement, in general, is not only a place to live for the transmigration community but it also a unit that would change the fate of the community and profitable for them as well as the local society. The life quality of the transmigrant was strongly determined by the condition of their settlement. It was in this matter the government should play an active role in achieving a settlement that is feasible for a place to live, for business, and for development. Transmigration settlement that did not meet the feasibility standards could give direct impact on its inhabitants, which was the transmigration community. To avoid the problem, the synchronization of the roles of government as regulator, facilitator, and dynamic driving forces/driver or as a supervisor should run as optimal as possible in the implementation of transmigration program in the region and particularly in maintaining the existence of transmigration settlement in rural areas.

The roles of the local government of Kutai Kertanegara Regency are an interconnected system that should work according to their own portion. In the context of transmigration settlement, if the roles did not work it would bring negative impact on the sustainability of transmigration settlement in their own areas, as indicated by the case in this paper, which was endangering the existence of transmigration settlement in Mulawarman Village. Due to the problems in transmigration settlement in Mulawarman Village Tenggarong Seberang Subdistrict Kutai Kertanegara Regency the existence of the settlement as the development area of transmigration settlement was endangered. The less maximum of roles of local government of Kutai Kertanegara Regency made the problems stay up to now with no certain solution.

Expectation toward the government was related to the following: First, the role of local government as a regulator is intended for the government to issue regulations or policies that could protect the existence of transmigration settlement and create programs that support the improvement of the life quality of transmigration community; second, the role of government as a facilitator is aimed to provide the society needs in order to support their activities that include physical development or basic services in the development of transmigration 
settlement; and third, the role of government as a dynamic driving forces requires the government to presence as a driver for transmigration community aspiration to achieve society needs-approach development in the transmigration settlement. However, based on the facts in transmigration settlement in Mulawarman Village, the roles of local government were in contrast to the expectation of transmigration community where they expect the government to give solution on problems they faced.

Based on the regulation aspect, up to now, the local government had not passed any proposed regional regulation developed by DPRD of Kutai Kertanegara Regency. Therefore, there were no policies that could be used as a guide for transmigration community to defend their rights, in this case the right to work with the availability of productive land and the right to live. In addition, since 2008, the productive land has been shifted into mining land and even the condition of transmigration settlement in Mulawarman Village was life threatening thus the transmigration community live in a miserable life. As for the proposed regional regulation initiated by the DPRD of Kutai Kertanegara Regency, it had not been approved by the local government that gave a strong indication on the insensitiveness of the government toward their role as a regulator in maintaining the existence of transmigration settlement in the area. Regarding the role of local government as a facilitator, the development of infrastructures needed by the community to support their activities had been an inseparable part of the difficulties faced by the community since, up to now, the local government had not realized the agreement made related to the demand of the transmigration community which was the creation of new rice fields, road repair, and clean water availability. In addition, those needs were the main part in supporting the existence of transmigration settlement to be a feasible settlement for the transmigrant. The role of local government as a dynamic driving forces/driver of society aspiration was also one of the cause for the endangered transmigration settlement in Mulawarman Village. In this context, the local government was unable to becoming the channel for society aspiration to create need-oriented development of transmigration community. Consequently, the community asked for assistance to the related central government to overcome problems occurred in transmigration settlement in Mulawarman Village. It increasingly indicated that the presence of local government as a dynamic driving force in maintaining the existence of transmigration settlement had brought distrust toward the government among the transmigration community.

Moreover, the research also found that there were three roles of local government in maintaining transmigration settlement, namely, regulator, facilitator and dynamic driving forces/driver that became the main focus of the research. In addition, the weak supervision of local government on the continuity of the existence of transmigration settlement caused the occurrence of problem of the uncontrolled activities of coal mining that suppressed the transmigration settlement and if the local government unaware of the problem it could impact other transmigration settlements in the area of Kutai Kertanegara Regency.

\section{CONCLUSION}

The role of local government as regulator, facilitator and dynamic driving force/driver in maintaining the existence of the endangered transmigration settlement in Mulawarman Village had some weaknesses in their implementation in order to support the implementation of transmigration program in the region. In regulator aspect, the local government had not issued any policy or regulations related to efforts in protecting or maintaining the existence of transmigration settlement in the region.

The role of local government as a facilitator tended to be slow in realizing the needs of transmigration community. The needs were related to the availability of new productive lands, 
road repair, and clean water. There were no real steps from the local government regarding the provision of the needs.

Meanwhile, the role of local government as a dynamic driving force/driver had not been able to become an umbrella for transmigration community to channel their aspiration related to the condition and problems they faced. The weak of supervision from the government caused mining activities expanded and the impact of pollution was uncontrolled in the transmigration settlement and its surrounding areas. What the local government could do regarding the threat of the extinction of transmigration settlement in the village is by maximizing their roles through periodic evaluation and inventory related to the condition of transmigration settlement in their areas thus their action could be sustainable with the existence of transmigration settlement.

\section{References}

Creswell, John W. 2016. Reserarch Desaign: Pendekatan Metode Kualitatif, Kuantitatif, dan Campuran. Yogyakarta: Pustaka Pelajar.

Fitriyah, Farida. 2016. Hukum Pengadaan Tanah Transmigrasi: Kebijakan Pengadaan dan Sertifikasi Hak Atas Tanah Untuk Transmigrasi. Malang: Setara Press.

Heeren, H.J. 1979. Transmigrasi di Indonesia. Jakarta: PT Gramedia.

Labolo, Muhadam. 2007. Memahami Ilmu Pemerintahan : Suatu Kajian, Teori, Konsep, dan Pengembabgannya. Jakarta: PT Raja Grapindo Persada.

Labolo, Muhadam, dkk. 2015. Dialektika Ilmu Pemerintahan. Bogor: Ghalia Indonesia.

Muttalib, M.A dan Khan, Mohd. Ali. 2013. Theory Of Local Government (Teori Pemerintahan Daerah).MIPI. Jakarta.

Moleong, Lexy J. 2004. Metodologi Penelitian Kualitatif. Bandung: Remaja Rosda Karya.

Ndraha, Taliziduhu. 2003. Kybernology (Ilmu Pamerintahan Baru). Jakarta: PT Rinaka Cipta.

Ndraha, Taliziduhu. 2005. Kybernologi: Sebuah Rekonstruksi Ilmu pemerintahan. Jakarta: PT Rineka Cipta.

Poelje, G.A. Van 1953. Pengantar Umum Ilmu Pemerintahan. Terjemahan B. Mang Reng Say. Jakarta: N.V Seoroengan.

PPSM. 1980. Pemantapan Usaha Pembangunan di Daerah Transmigrasi. Jakarta.

Rosidi, Abidarin dan Fajriani, Anggraeni. 2013. Reinventing Government: Demokrasi dan Reformasi Pelayanan Publik. Yogyakarta:C.V Andi Offset (Penerbit Andi).

Sardjadidjaja, Rukman. 2004. Transmigrasi: Pembauran dan Intergrasi Nasional. Jakarta: Pustaka Sinar Harapan.

Sedarmayanti. 2012. Good Governance: Kepemerintahan Yang Baik: Membangun Sistem Mananjemen Kinerja Guna Meningkatkan Produktivitas Menuju Good Governance. Bandung: CV. Mandar Maju.

Sugiyono. 2009. Memahami Penelitian Kualitatif. Bandung: Alfabeta

Suharto, Didik G. 2016. Membangun Kemandirian Desa (perbandingan UU No. 5/1979, UU No. 22/1999, dan UU No. 32/2004 serta Perspektif UU No. 6/2014). Yogyakarta: Pustaka Pelajar.

Suparno, Erman. 2008. Paradigma Baru Transmigrasi Menuju Kemakmuran Rakyat. Departemen Tenaga Kerja dan Transmigrasi RI

Syafiie, Inu Kencana. 1994. Ilmu Pemerintahan. Bandung: Mandar Maju.

Syafiie, Inu Kencana. 2011. Etika Pemerintahan: Dari Keseimbangan Good Governamce dengan Clean Government: Ilmu Pemerintahan Dalam Mengubah Pemerintah Biadab Menjadi Pemerintah Beradab. Jakarta: Rineka Cipta. 